\title{
EVALUATION OF ALTERNATIVE COMPONENTS IN GROWTH MEDIA OF LACTOBACILLUS BREVIS FOR HALAL PROBIOTIC PREPARATION
}

\author{
Riyona Desvy Pratiwi ${ }^{1,{ }^{*}}$, Sabighoh Zanjabila ${ }^{1}$, Dian Fairuza ${ }^{1}$, Aminah $^{1}$, Swastika \\ Praharyawan $^{1}$, Asrul Muhamad Fuad ${ }^{1}$ \\ ${ }^{1}$ Research Center for Biotechnology, Indonesian Institute of Sciences, Indonesia
}

\begin{abstract}
Probiotic has been widely used in functional food because of numerous advantages for health. MRS broth is commonly used as standard medium in studying lactobacilli. However, in some communities - like muslim and vegetarian society, components in MRS broth/medium become an issue. Beef extract and peptone - animal derived substances as nitrogen sources in the MRS medium should be avoided for the vegetarian. Meanwhile, for the muslim society, all components must be halal-certified including those animal derived ingredients. Therefore, several alternative sources for beef extract and peptone substitution were studied. Combination of alternative nitrogen sources was applied. In order to increase the effect of the alternative nitrogen sources, alternative carbon sources were also included. This is the first report about effects of $L$. brevis media components on cells growth to expression level of surface layer protein (Slp). Whey, lactose, sucrose, and galactose showed high contribution to L. brevis growth. However, the tested concentration of those substances were not sufficient to obtain equal bacterial growth and Slp expression than that of MRS broth. In addition, yeast extract appeared necessary to maintain cell wall and Slp expression.
\end{abstract}

Keywords: alternative nitrogen sources, halal growth medium, Lactobacillus brevis, S-layer protein

"Corresponding author: Riyona Desvy Pratiwi

Cibinong Science Center, Jl. Raya Bogor Km. 46, Cibinong 16911, Indonesia

Tel. +62-21-8754587, Fax. +62-21-8754588

E-mail. riyona.desvy.pratiwi@lipi.go.id

\section{Introduction}

De Man, Rogosa, and Sharge (MRS) broth has been commonly used as standard medium in studying alternative media for lactic acid bacteria such as Lactobacillus brevis (de Man, et al, 1960; Yoo, et al., 2018; Ramadani, et al., 2014; Utami, et al., 2019). The main components in the medium are protein or nitrogen rich-sources such as tryptic digest of casein, beef extract and yeast extract. However, this leads issue in several communities. In India, free animal components medium is highly needed due to concern in food for vegetarian (Pathak and Martirosyan, 2012). Moreover, in muslim population, halal is the most important requirement (Kurniadi and Ferdiansyah, 2017).

According to Kurniadi and Ferdiansyah (2017), halal perception in microbes containing product includes source of the microbe; microbial isolate; growth substrate; metabolism product; and other components added during the process. Therefore, MRS broth as the growth substrate must content halal ingredient. In the recent study, tryptic digest of casein and beef extract in the MRS broth were removed because it is often making a doubtful that those components are generated from halal sources. Meanwhile, yeast extract is halal, only if during its preparation, no haram ingredients/processes are included (Riaz and Chaudary, 2017). As consequent, they are substituted with other ingredients that have been identified as halal food ingredients, for instance whey (Ramadhani, 2014) and soy (Coghetto, 2016).

Whey is translucent liquid that remains on the surface of a fermented milk product like cheese. It is separated with casein that being precipitated as the result of the fermentation (Ansari, et al, 2017). Whey contains all of essential amino acid and other protein based nutrition such as lactoferrin, beta- 
lactoglobulin, alpha-lactalbumin, and immunoglobulin (de Wit, 1998; Marshall, 2004). The advantages of whey in growth medium for lactobacilli have been reported (Miloud, et al, 2017; Burns, et al, 2008; Ansari, et al, 2017). In addition, whey water shows almost equivalent capacity in growth of Lactobacillus sp. compared with MRS broth (Ansari, et al, 2017).

Besides whey, soy was used as a representative of vegetable protein source. Soy contains high protein that is almost $40 \%$ of its dried weight (Sharma, et al, 2014; Nishinari, 2014). Yoo, et al (2018) reported that growth medium with optimized soy-peptone showed beneficial effect on L.plantarum growth. In order to enrich the medium, sole carbon sources, namely lactose, galactose, and sucrose were also tested.

In the recent study, several of the mentioned alternative components which showed significant effect for the $L$. brevis growth were selected. Moreover, not only assessing the cell growth, production level of surface layer protein (Slp) - a crucial protein for probiotic attachment to intestine was also investigated. To our knowledge, this is the first study exploring the potency of alternative halal components for Lactobacillus or particularly $L$. brevis for growth thereof which also provides analysis of the Slp expression.

\section{Materials and Methods}

\section{Materials}

Lactobacillus brevis B144 (Indonesian Culture Collection or InaCC); De Man, Rogosa, and Sharge (MRS) broth (Merck); yeast extract (Caisson); glucose; sodium acetate; polysorbate 80 ; dipottasium hydrogen phosphate; triammonium citrate; magnesium sulphate; galactose; sucrose; lactose; HybriScan $^{\mathrm{TM}}$ Lactobacillus brevis for microbiology (all components were purchased from Sigma); whey powder (Bonigrasa); soy powder (Mahkota).

\section{Methods}

Preliminary study on influence of animal derived component and yeast derived component of MRS medium in growth curve of $L$. brevis.
Pre-culture was prepared from a $L$. brevis single colony that was grown in $1 \mathrm{~mL}$ of MRS broth ( $24 \mathrm{~h}$, room temperature, $200 \mathrm{rpm})$. One $\mathrm{ml}$ of the pre-culture was poured into $10 \mathrm{ml}$ of each media, namely MRS broth, MRS(-) with $0.4 \%$ yeast extract, and MRS(-).

MRS broth was used as standard of complete nitrogen sources containing peptone, beef and yeast extract. On the other hand, MRS (-) with yeast extract was prepared from components of commercial MRS, but not added with beef extract and peptone. Another medium, MRS(-) or negative control was without all of nitrogen sources (yeast extract, beef extract, and peptone). It contained $2 \%$ glucose; $0.5 \%$ sodium acetate; $0.1 \%$ polysorbate $80 ; 0.2 \%$ dipottasium hydrogen phosphate; $0.2 \%$ triammonium citrate; and $0.02 \%$ magnesium sulphate.

Culture sampling was carried out everyday at $0 ; 2 ; 4 ; 6$; and $8 \mathrm{~h}$, for 4 days or $80 \mathrm{~h}$. Optical density (OD) of each sample was measured using spectrophotometer (UV Pharmaspec 1700 Shimadzu) at $600 \mathrm{~nm}$. Samples with original OD $>1$ was diluted to obtain final OD in range 0.2-0.8.

Screening of carbon and nitrogen sources as alternative components to substitute animal and yeast derived component in MRS broth.

Pre-culture was prepared from a single colony of $L$. brevis and incubated in $1 \mathrm{ml}$ of MRS broth for $24 \mathrm{~h}$, room temperature, 200 $\mathrm{rpm}$. The first pre-culture was refreshed in 10 $\mathrm{ml}$ of MRS broth and then incubated for $36 \mathrm{~h}$ at room temperature. The $1 \mathrm{ml}$ second preculture was added to $10 \mathrm{ml}$ of tested media which had been prepared following the Table 1.

Alternative sources of nitrogen (whey and soy powder) and carbon (galactose, sucrose, and lactose) were used in this study. We used minimum - maximum percentage of the components by following Pathak et al (2012) (Table 2). Plackett-Burman design was used with seven variables as described in Table 1 (Rekab and Shaikh, 2005).

The $L$. brevis was incubated in the tested media for $72 \mathrm{~h}$, room temperature, $200 \mathrm{rpm}$. Afterwards, for total plate count (TPC) analysis, $100 \mu \mathrm{l}$ of cell culture was diluted until $10^{-6}$ and spread on MRS agar. As positive control, culture in $10 \mathrm{ml}$ of MRS was also prepared. 
Table 1. Placket-Burrman design with seven variables

\begin{tabular}{cccccccc}
\hline Media & W-fil. & S-fil. & L & G & S & $\begin{array}{l}\text { W- } \\
\text { unfil. }\end{array}$ & $\begin{array}{c}\text { S- } \\
\text { unfil. }\end{array}$ \\
\hline 1 & + & - & - & + & - & + & + \\
2 & + & + & - & - & + & - & + \\
3 & + & + & + & - & - & + & - \\
4 & - & + & + & + & - & - & + \\
5 & + & - & + & + & + & - & - \\
6 & - & + & - & + & + & + & - \\
7 & - & - & + & - & + & + & + \\
8 & - & - & - & - & - & - & - \\
\hline
\end{tabular}

Note: (+) maximum concentration; (-) minimum concentration; W-fil : filtered whey; S-fil : filtered soy; L: lactose; G: galactose; S: sucrose; W-unfil : unfiltered whey; S-unfil : unfiltered soy

Table 2. Maximum and minimum concentration of each alternative source

\begin{tabular}{cccc}
\hline Code & $\begin{array}{c}\text { Alternative } \\
\text { source }\end{array}$ & $\begin{array}{c}\text { Maximum } \\
\text { concentration } \\
(\%)\end{array}$ & $\begin{array}{c}\text { Minimum } \\
\text { concentration } \\
(\%)\end{array}$ \\
\hline A & Whey- & 2 & 0 \\
B & filtered & 1 & 0 \\
C & Lactiltered & 2 & 0 \\
D & Galactose & 2 & 0 \\
E & Sucrose & 2 & 0 \\
F & Whey- & 2 & 0 \\
G & unfiltered & & 0 \\
\hline
\end{tabular}

Effect value for each component (Table 5) was calculated by using the following formula:

$$
\text { Effect }=\frac{2\left[\sum \mathrm{R}(\mathrm{H})-\sum \mathrm{R}(\mathrm{L})\right]}{\mathrm{N}}
$$

Where $\mathrm{R}(\mathrm{H})$ is all responses when component was at high levels, $\mathrm{R}(\mathrm{L})$ is all responses when component was in low levels, and $\mathrm{N}$ is total number of runs.

For example, effect value for $\mathrm{W}$-fil $=$ $\{(+)$ TPC Media $1+(+)$ TPC Media $2+(+)$ TPC Media $3+(-)$ TPC Media $4+(+)$ TPC Media 5 $+(-)$ TPC Media $6+(-)$ TPC Media $7+(-)$ TPC Media 8$\} /$ Lmedia $=2[(5+0+4.7-3.1+5-$ $2.3-2.4-2.4)] / 8=9 / 8=1.125$

\section{Effect of animal free based media to surface layer protein of $L$. brevis.}

Culture preparation followed the procedure in the Method 2. Compositions of media are listed in Table 3. Growth of $L$. brevis was analyzed with a rapid detection using HybriScan ${ }^{\circledR}$ for $L$. brevis kit and TPC. For the Slp expression analysis, the protein was isolated following procedure in Viljanen and Palva (2007). The protein was quantified with ImageJ software using bovine serum albumin (BSA) as protein standard. Statistic analysis was performed using One way ANOVA and Pos hoc test Tukey and LSD with significance level 0.05 (SPSS version 26 2019).

Table 3. Components in tested media

\begin{tabular}{|c|c|c|c|c|}
\hline Component & $\begin{array}{l}\text { MRS (-) } \\
\text { (Negative } \\
\text { control) }\end{array}$ & $\begin{array}{c}\text { Medium } \\
\mathrm{A}\end{array}$ & $\begin{array}{l}\text { Medium } \\
\mathrm{B}\end{array}$ & $\begin{array}{c}\text { MRS } \\
\text { (Positive } \\
\text { control) }\end{array}$ \\
\hline $1 \%$ peptone & - & - & - & $\sqrt{ }$ \\
\hline $\begin{array}{l}1 \% \text { beef } \\
\text { extract }\end{array}$ & - & - & - & $\sqrt{ }$ \\
\hline $\begin{array}{l}0.4 \% \text { yeast } \\
\text { extract }\end{array}$ & - & $\sqrt{ }$ & - & $\sqrt{ }$ \\
\hline $2 \%$ glucose & $\sqrt{ }$ & $\sqrt{ }$ & $\sqrt{ }$ & $\sqrt{ }$ \\
\hline $\begin{array}{l}0.5 \% \text { sodium } \\
\text { acetate }\end{array}$ & $\sqrt{ }$ & $\sqrt{ }$ & $\sqrt{ }$ & $\sqrt{ }$ \\
\hline $\begin{array}{l}0.1 \% \\
\text { polysorbate } 80\end{array}$ & $\sqrt{ }$ & $\sqrt{ }$ & $\sqrt{ }$ & $\sqrt{ }$ \\
\hline $\begin{array}{l}0.2 \% \\
\text { dipottasium } \\
\text { hydrogen } \\
\text { phosphate }\end{array}$ & $\sqrt{ }$ & $\sqrt{ }$ & $\sqrt{ }$ & $\sqrt{ }$ \\
\hline $\begin{array}{l}0.2 \% \\
\text { triammonium } \\
\text { citrate }\end{array}$ & $\sqrt{ }$ & $\sqrt{ }$ & $\sqrt{ }$ & $\sqrt{ }$ \\
\hline $\begin{array}{l}0.02 \% \\
\text { magnesium } \\
\text { suphate }\end{array}$ & $\sqrt{ }$ & $\sqrt{ }$ & $\sqrt{ }$ & $\sqrt{ }$ \\
\hline $\begin{array}{l}0.005 \% \\
\text { manganese } \\
\text { sulphate }\end{array}$ & - & - & - & $\sqrt{ }$ \\
\hline $2 \%$ lactose & - & $\sqrt{ }$ & $\sqrt{ }$ & - \\
\hline $2 \%$ galactose & - & $\sqrt{ }$ & $\sqrt{ }$ & - \\
\hline $2 \%$ whey & - & $\sqrt{ }$ & $\sqrt{ }$ & - \\
\hline
\end{tabular}

\section{Results}

Preliminary study on influence of animal derived and yeast derived component of MRS media on growth curve of $L$. brevis.

Figure 1 shows growth curve of L. brevis which was incubated in various media. Different trends of growth curve were obtained (Figure 1). MRS broth or positive control gave the longest log phase among those media. In the experiment time set, it had not achieved stationary phase yet, meaning that the OD might still increase. On contrary, the culture showed the slowest growth in MRS(-) as a negative control. After $80 \mathrm{~h}$, the final OD was less than 1. Supplementation of yeast extract in the MRS(-) contributed to improvement of the growth curve, even though it was approximately an half of the MRS. After $24 \mathrm{~h}$, stationary phase was achieved. 


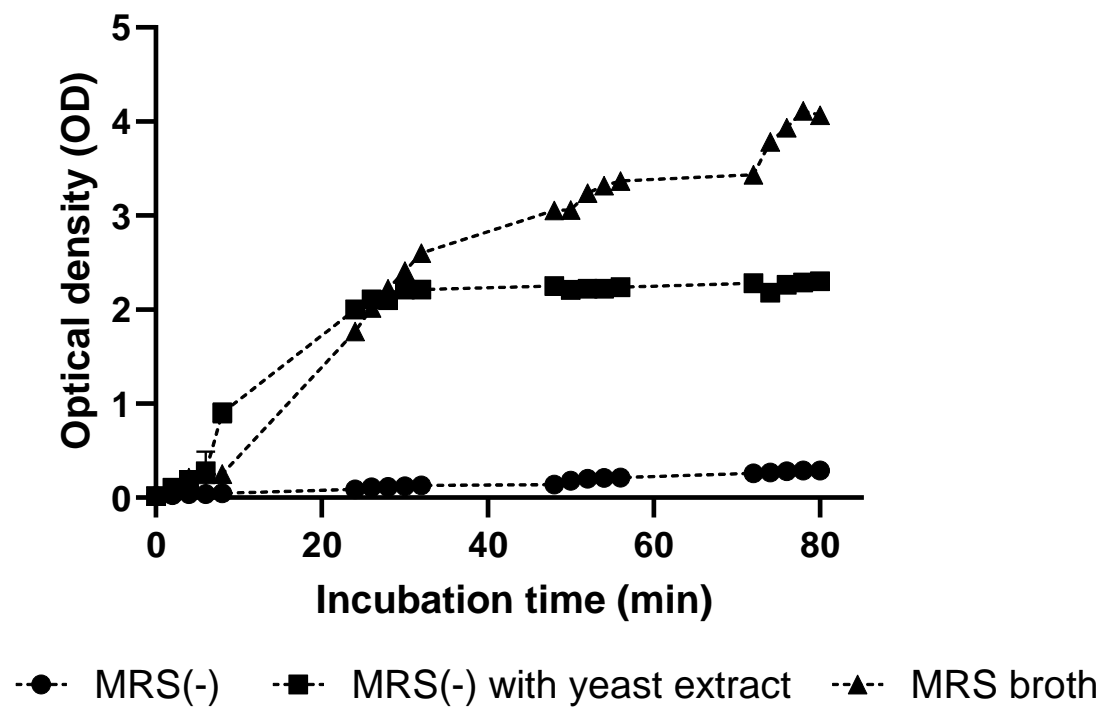

Figure 1. Growth curve of L. brevis in MRS media with and without animal/yeast derived

\section{Screening of carbon and nitrogen sources as alternative components to substitute animal derived component in MRS.}

Whey and soy bean powder were screened to investigate their potency to substitute beef extract and peptone. Filtration which was aimed to remove insoluble materials of whey and soy showing less discrepancy in their effect on cell growth as calculated by TPC (Table 4).

Table 4. Total plate count of media containing alternative nitrogen and carbon sources

\begin{tabular}{ccccccccl}
\hline Media & $\begin{array}{l}\text { W- } \\
\text { fil. }\end{array}$ & $\begin{array}{l}\text { S- } \\
\text { fil. }\end{array}$ & L & G & S & $\begin{array}{l}\text { W- } \\
\text { unfil. }\end{array}$ & $\begin{array}{l}\text { S- } \\
\text { unfil. }\end{array}$ & $\begin{array}{l}\text { TPC } \\
\left(\times 10^{7}\right)\end{array}$ \\
\hline 1 & + & - & - & + & - & + & + & 5 \\
2 & + & + & - & - & + & - & + & ND or 0 \\
3 & + & + & + & - & - & + & - & 4.7 \\
4 & - & + & + & + & - & - & + & 3.1 \\
5 & + & - & + & + & + & - & - & 5 \\
6 & - & + & - & + & + & + & - & 2.3 \\
7 & - & - & + & - & + & + & + & 2.4 \\
8 & - & - & - & - & - & - & - & 2.4 \\
\hline
\end{tabular}

Soy and sucrose gave negative effect value meaning that, theoretically, these two components require lower concentration than the current concentration applied in order to give high cell growth response. Other sources such as whey, lactose, and galactose showed positive effect value. Carbon sources (lactose, galactose, and sucrose) indicated higher contribution which was $>20 \%$ than that of nitrogen sources. Galactose most dominantly contributed among other components $(23.77 \%)$. On contrary, filtered soy showed the lowest contributed, only $0.34 \%$. Filtered whey was the highest contributor among other nitrogen sources (13.83\%), followed by unfiltered whey and soy (Table 5). Therefore, for the next experiment whey was selected instead of soy because of low contribution from filtered soy.

Table 5. Effect, sum of squares and contribution of each component

\begin{tabular}{cccc}
\hline $\begin{array}{c}\text { Alternative } \\
\text { source }\end{array}$ & Effect & $\begin{array}{c}\text { Sum of } \\
\text { Squares }\end{array}$ & $\begin{array}{c}\text { Contribution } \\
(\%)\end{array}$ \\
\hline W-fil & 1.125 & 2,53 & 13,83 \\
S-fil & -1.175 & 0,06 & 0,34 \\
L & 1.375 & 3,78 & 20,65 \\
G & 1.475 & 4,35 & 23,77 \\
S & -1.375 & 3,78 & 20,65 \\
W-unfil & 0.975 & 1,90 & 10,38 \\
S-unfil & -0.975 & 1,90 & 10,38 \\
\hline
\end{tabular}

Effect of animal free derived media to surface layer protein of $L$. brevis.

In this experiment, the selected components that resulted positive coefficient (whey, lactose, and galactose) were added into MRS() with yeast extract (Medium A) and MRS(-) (Medium B) (Table 3). Those media were compared with MRS(-) as negative control and MRS broth as positive control. 


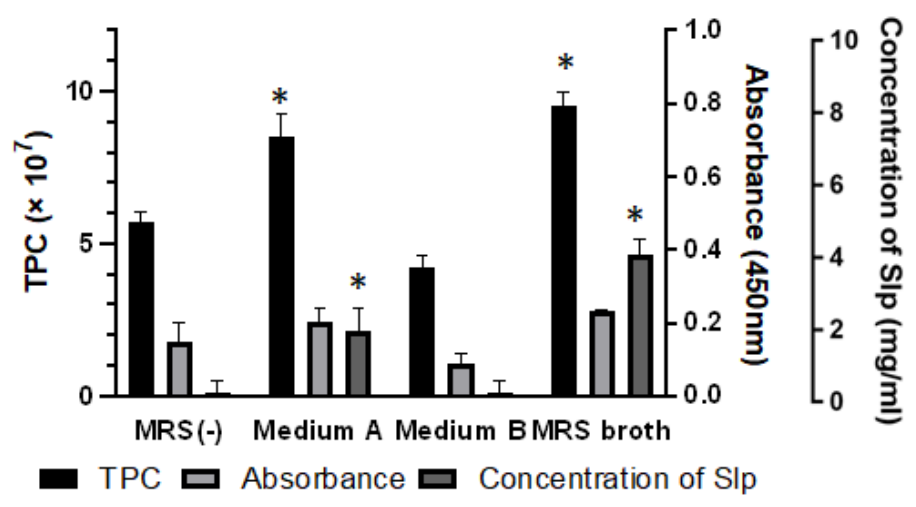

Figure 2. Number of live bacterial colonies (HybriScan absorbance and total plate count) and concentration of Slp $(\mathrm{p}<0.05)$

Figure 2 shows that addition of $2 \%$ whey, $2 \%$ lactose, and $2 \%$ galactose to MRS(-) did not increase bacterial growth. In line with that, expression of Slp was also low. Surprisingly, supplementation of $0.4 \%$ yeast extract significantly increase bacterial growth and Slp expression. The highest cell growth and Slp expression were obtained from MRS broth. Absorbance value of HybriScan ${ }^{\circledR}$ L. brevis kit proved that the colonies are positively $L$. brevis identified.

Figure 3 depicts the abundant of Slp which was expressed in Medium A and MRS broth ( $45 \mathrm{kDa}$ ). Medium A resulted in $2.15 \mathrm{mg} / \mathrm{ml}$ of Slp from whole harvested cells or $0.28 \mathrm{mg} / \mathrm{ml}$ from $1 \times 10^{7} \mathrm{cfu}$, while MRS broth resulted 4.64 $\mathrm{mg} / \mathrm{ml}$ from whole harvested cells or 0.52 $\mathrm{mg} / \mathrm{ml}$ from $1 \times 10^{7} \mathrm{cfu}$.

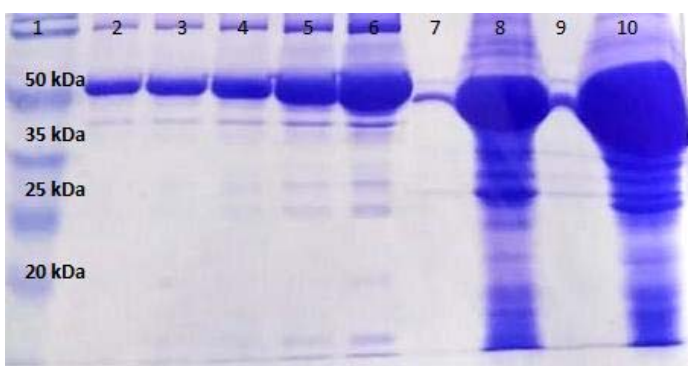

Figure 3. SDS PAGE profile of S-layer protein (Slp) of the tested media (Lane 7: Slp in negative control; Lane 8: Slp in Medium A; Lane 9: Slp in medium B; Lane 10: Slp in positive control or MRS broth; and BSA standard in a serial concentration Lane $2-6(0.125 \mathrm{mg} / \mathrm{ml} ; 0.25 \mathrm{mg} / \mathrm{ml}$; $0.5 \mathrm{mg} / \mathrm{ml} ; 1 \mathrm{mg} / \mathrm{ml} ; 2 \mathrm{mg} / \mathrm{ml}$; Lane 1: protein marker). $y=7102 x+7095, r^{2}=0.93$. ( $y=$ area detected by Image $;$ x $=$ concentration $(\mathrm{mg} / \mathrm{ml})$

\section{Discussion}

Beef extract, peptone, and yeast extract obviously affected $L$. brevis growth. With respect to our preliminary study, without those components, $L$. brevis hardly grew. Supplemented with yeast extract, growth of $L$. brevis increased an half of that of in MRS broth. Seesuriyachan and colleagues (2009) reported that without yeast extract, beef extract, and peptone, L.confusus TISTR 1498 was obtained in extremely low yield.

Beef extract contains of complete protein, peptide and amino acids, numerous vitamins particularly vitamin B complex, creatine and creatinine. Yeast extract is commonly used to substitute beef extract, however it is lack of creatine and creatinine (Pearson, 2003).

From the screening study, we concluded that whey, lactose, and galactose are essential for $L$. brevis growth. Lactose is known to be the main energy source from beef extract (Pearson, 2003). Whey is composed of proteins, lactoperoxidase, and peptone (de Wit, 1998). However, in the current study, addition of $2 \%$ of whey, lactose, and galactose appeared not giving significant difference with negative control regarding to TPC and Slp expression. In line with the positive effect value, those components require higher concentration to reach optimized condition which could be calculated with response surface methodology (El-Hamid, et al, 2018).

TPC and HybriScan ${ }^{\circledR}$ were combined to gain information on live $L$. brevis specific cells count. TPC was applied to directly count number of live colonies. This method is low-cost, yet complicated, requires incubation time, and not 
able to distinguish species (Hazan, et al, 2012). HybriScan ${ }^{\circledR}$ for $L$. brevis is a qualitative method which detects specific rRNA from live L. brevis. Absorbance value from HybriScan ${ }^{\circledR}$ for $L$. brevis kit does not responsible to number of live cells, but only to confirm whether the sample is positive L. brevis or not (HybriScan ${ }^{\circledR}$ Rapid Test Guideline).

According to the TPC data, it is assumed that concentration of the components that we used were not sufficient to enhance $L$. brevis growth. Ramadhani (2014) used 5\% whey for L.plantarum Dad 13 halal media. Unfortunately, comparison with MRS media was not included. Tofu whey $(100 \%)$ was used to substitute MRS broth for Pediococcus pentosaceus. MRS broth resulted $\log 10 \mathrm{cfu}$, while tofu whey resulted $\log$ $8.5 \mathrm{cfu}$ (Safitri, et al, 2016). Ansari, et al (2017) used $100 \%$ of whey water to obtained $\mathrm{OD}_{600}=$ 0.95 of $L$. sporogenes, whereas $\mathrm{OD}_{600}=1.10$ was obtained from MRS broth as positive control.

Zammaretti and colleagues (2005) reported that yeast extract and peptone are obliged to be included in growth media for Lactobacillus. Those substances are necessary for the bacterial cell wall. Variation of protein compositions in growth media alters surface charge and hydrophobicity of Slp. Moreover, without yeast extract and peptone the Slp was significantly less intensed, observed under transmission electron microscope (TEM) (Zammaretti, et al, 2005). This clearly explained our finding in which remarkable increase of Slp expression in media with $0.4 \%$ yeast extract than without yeast extract was observed. Therefore, either yeast extract or peptone should not be substituted with other components, yet preparing such halal materials is highly considered.

Study on preparation of halal peptone from meat and soybean using bromelain, a specific enzyme from pineapple has been started. Those halal peptones appeared promising, however, their potential was still not adequate compared with MRS broth (Utami, et al, 2019).

Compounding a novel and halal growth media for Lactobacillus with superior quality than MRS broth is considered challenging. This commercial media was thoughful optimized and has been used for five decades (de Man, et al, 1960). However, whey in appropriate concentration showed high potency to substitute MRS broth. A hundred percent of whey added with yeast extract and halal processed-peptone is respected as competent as MRS broth (Safitri, et al, 2016; Ansari, et al, 2017; Utami, et al, 2019). Whey has been also explored as more economical component to replace beef extract. By using $100 \%$ halal-whey, others chemical substances which are not entirely halal certified, might be excluded. In addition, appropriately washed yeast extract has been announced halal by Majelis Ulama Indonesia (Fatwa MUI, 2011). According to the mentioned previous results, optimization of whey concentration is more crucial than carbon sources concentration. However, in order to obtain the exactly optimized concentration of whey, a response surface methodology is needed.

\section{Conclusion}

Beef extract, yeast extract, and peptone are the most important ingredients or nitrogen sources in medium for $L$. brevis affecting cells growth. Substitution or reduction of those components significantly affect the cells growth and Slp expression. For preparation of halal medium, those components are required to be processed following halal products guideline. Turning to another potential nitrogen source, whey has been commonly produced as halal ingredient. However, to obtain equal quality than MRS broth, high concentration of whey is needed. A response surface methodology is suggested to calculate the optimized concentration of whey in terms of alternative nitrogen source for $L$. brevis growth medium.

\section{Acknowledgements}

The authors would like to thank to Ministry of Research and Higher Education, Republic of Indonesia for the financial support on the Incentive for National Innovation of Functional Foods Flagship, Indonesian Institute of Sciences 2018.

\section{References}

Ansari, N.F., Chetana, A., Prasad, E.M., Birajdar, R., Naidu, N.V (2017). Evaluation of whey water as growth medium for Lactobacillus species. International Journal of Applied Biology and Pharmaceutical Technology, 8(1):38-42. http://dx.doi.org/10.21276/ijabpt

Burns, P. (2008). Suitability of whey and buttermilk for the growth and frozen storage of probiotic lactobacilli. International Journal of Dairy Technology, 61(2):156164.http://dx.doi.org/10.1111/j.1471-0307. 2008.00393.x

Chogetto, C.C., Vasconselos, C.B., Brinques, G.B., Ayub, M.A.Z. (2016). Lactobacillus 
plantarum BL011 cultivation in industria isolated soybean protein acid residue. Brazilian Journal of Microbiology, 47:941-948. http://dx.doi.org/10.1016/j.bjm.2016.06.003

El-Hamid, HTA., A-Prol, AE., Hafiz, MA. (2018). Plackett-Burman and response surface methodology for optimization of oily wastewater bioremediation by Aspegillus sp. South Asian Journal of Research in Microbiology. 2(1): 1-9

Fatwa MUI No. 102011 tentang Cara Pensucian Extract Ragi dari Sisa Pengolahan Bir (Brewer's Yeast).

Hazan, R., Que, Y.A., Maura, D., Rahme, L.G. (2012). A method for high throughput determination of viable bacteria counts in 96well plates. BMC Microbiology, 12(259) : 1-7. doi : 10.1186/1471-2180-12-259

HybriScan ${ }^{\circledR} \quad$ Rapid Test Guideline, https://www.sigmaaldrich.com/analyticalchromatography/microbiology/identificationtests/hybriscan-rapid-test.html, [accessed October, 17 2019]

Kurniadi, M., Frediansyah, A. (2016). Perspektif Halal Produk Pangan Berbasis Bioproses Mikrobia. Reaktor, 16(3):147-160 [in bahasa Indonesia]. http://dx/doi.org/10.14710/reaktor. 16.3.147-160

de Man, J.D., Rogosa, M., Sharpe, M.E. (1960). A medium for the cultivation of Lactobacilli, Journal of Applied Bacteriology, 23: 130-135

Marshall, K. (2004). Therapeutic applications of whey protein. Alternative Medicine Review, 9(2):136-156

Miloud B. (2017). Development of a sweer whey-based medium for culture of Lactobacillus. African Journal of Biotechnology, 16(30):1630-1637. http://dx.doi.org/10.5897/AJB2017.16088

Nishinari, K., Fang, Y., Guo, S., Philips, G.O. 2014. Soy proteins: a review on composition, aggregation and emulsification. Journal of Food Science Technology, 51(3):551-557

Pathak, M., Martirosyan, D. (2012). Optimization of an effectice growth medium for culturing probiotic bacteria for applications in strict vegetarian food products. Functional Foods in Health and Disease, 2(10):369-378

Pearson, A.M. in Encyclopedia of Food Sciences and Nutrition (Second Edition). (2003). Meat Extract, 3812-3817, Corvallis, Academic Press. doi://10.1016/B0-12-227055-X/00758-6

Ramadhani, A.D. (2014). Pengembangan Media Halal Berbasis Whey untuk Pertumbuhan Lactobacillus plantarum Dad 13. Skripsi. Yogyakarta: Fakultas Teknologi Pangan Universitas Gadjah Mada [in bahasa Indonesia]

Rekab,. K \& Shaikh, M. (2005). Statistical Design of Experiment with Engineering Application, CRC Press, Boca Raton
Riaz, M.N. \& Chaudary, M.M. (2003). Halal Food Production $1^{\text {st }}$ Edition, CRC Press, Boca Raton

Safitri, N., Sunarti, T.C., Meryandini, A. (2016). Formulation of whey tofu-based medi for the cultivation of lactic acid bacteria Pediococcus pentosaceus, Jurnal Sumberdaya Hayati, 2(2) : 31-33

Seesuriyachan, P., Kuntiya, A., Hanmoungjai, P., Techapun, C. (2011). Exopolysaccharide production by Lactobacillus confusus TISTR 1498using coconut water as an alternative carbon source: the effect of peptone,yeast extract and beef extract, Songklanakarin Journal of Science and Technology, 33(4) : 379-387

Sharma, S., Kaur, M., Goyal, R., Gill, B.S. (2014). Physical characteristics and nutritional composition of some new soybean (Glycine max (L.) Merill) genotypes. Journal of Food Science Technology, 51(3):551-557. doi: /10.1007/s13197-0110517-7

Utami, T., Kusuma, E.N., Satiti, R., Rahayu, E.S., Cahyanto, M.N. (2019). Hydrolyses of meat and soybean proteins using crude bromelain to produce halal peptone as a complex nitrogen source for the growth of lactic acid bacteria. International Food Research Journal, 26(1) : $177-122$

Viljanen-Jakava, M., Palva, A. (2007). Isolation of surface (S) layer protein carrying Lactobacillus species from porcine intestine and faeces and characterization of their adhesion properties to different host tissues. Veterinary Microbiology, 124(3-4):264-273

de Wit, J.N., (1998). Nutritional and functional characteristics of whey proteins in food products. Journal of Diary Science, 81(3): 597608. doi : 10.3168/jds.S0022-0302(98)756139.

Yoo, H., Rheem, I., Rheem, S., O.H, S. 2018. Optimizing medium components for the maximum growth of Lactobacillus plantarum JNU 2116 using response surface methodology. Korean Journal for Food Science of Animal Resources, 38(2):240-250.http://dx.doi.org/10.5851/kosfa. 2018.38.2.240

Zammaretti, P.S., Dillman, M.L., D’Amico, N., Affolter, M., Ubbink, J. (2005). Influence of Fermentation Medium Composition on Physicochemical Surface Properties of Lactobacillus acidophilus. Applied and Environmental Microbiology, 71(12) : 81658173. doi:10.1128/AEM.71.12.8165-8173. 2005 